\title{
Effect of soaking on the nutritional quality of pequi (Caryocar brasiliense Camb.) peel flour
}

Beatriz dos Santos SIQUEIRA ${ }^{1}$, Manoel Soares SOARES JÚNIOR ${ }^{2 *}$, Kátia Flávia FERNANDES ${ }^{1}$, Márcio CALIARI ${ }^{2}$, Clarissa DAMIANI ${ }^{2}$

\begin{abstract}
Pequi peel comprises $76 \%$ of the whole fruit and it is discarded during consumption. Thus, pequi peel has been considered a solid residue, although it has potential for use in various applications. Limitations in the use of this material are mainly due to the lack of information of its nutritional composition, especially about the toxic or antinutritional factors. Soaking is often used to prepare complementary foods and has been reported to be beneficial for enhancing nutritive value. The effect of soaking on the nutritional quality of pequi peel flour was determined by measuring changes in chemical composition, antinutritional factors, total phenols and in vitro protein and starch digestibility. The results showed that $24 \mathrm{~h}$ of maceration increases the content of lipids (200\%), protein (28.3\%) and dietary fibber (31\%), while carbohydrate and ash content decreases. There were no haemagglutination activity or $\alpha$-amylase inhibitors, but it was detected the presence of phytic acid $\left(0.4 \mathrm{~g} 100 \mathrm{~g}^{-1}\right)$. The soaking reduced $8.5 \%$ phenols and $19.0 \%$ tannins, $6.2 \%$ protein digestibility, and was also effective to eliminate trypsin inhibitors, and increase starch digestibility (24.2\%). Soaking was efficient to improve nutritional characteristics of the pequi peel flour, opening up possibilities for its use in food formulations.
\end{abstract}

Keywords: phytates; trypsin inhibitors; hemagglutinating activity.

\section{Introduction}

Pequi (Caryocar brasiliense Camb.) is a globular fruit, drupe-type, containing from 1 to 4 stones which represent the dispersion units of the species (LORENZI, 2008). It is widely consumed in Brazil, mainly in the Cerrado, and its agro-industrial processing has increased the spread to nonproducing regions (VERA et al., 2007). Due to its unique flavor and nutritive value, pequi has potential for use in feeding and survival of a significant part of the Brazilian population (MELO JÚNIOR et al., 2004), and its agro-industrial processing could be an option for the sustainable development of the Cerrado region in Brazil.

Despite the growth in consumption, the portion consumed (internal mesocarp) represents only $8.5 \%$ of the whole fruit. The external mesocarp which consists of $76 \%$ of the whole fruit (VERA et al., 2007) is normally discarded during the fruit processing, although it has potential for use in various applications, such as pectin extraction, production of flour and bakery or confectionery products (SOARES JÚNIOR et al., 2009, 2010; SIQUEIRA et al., 2012).

Pequi peel flour is a food rich in total dietary fiber, total carbohydrates, ash, magnesium, calcium, manganese and copper, but poor in lipids, zinc and iron (SOARES JÚNIOR et al., 2009). However, there are still limitations to the use of this material, mainly due to the lack of information of its nutritional composition, especially about the toxic or antinutritional factors, which can reduce the activity of some enzymes, the biological action of several chemical compounds and the absorption of nutrients.

Anti-nutritional factors can interfere with the bioavailability of nutrients or even be toxic, making important their study before application in new products. Knowledge on the nutritional composition of foods is fundamental in order to evaluate the availability of nutrients and their consumption by populations, apart from verifying the nutritional adequacy of the diet, identifying the nutritional status, developing research concerning the relationship between diet and disease, and for use in agricultural planning and by the food industry (UNIVERSIDADE..., 2004). However it is known that knowledge of the nutrients in a food is not sufficient to evaluate its nutritional quality, since not all are totally available to the organism after digestion.

Soaking is a domestic technological treatment that is often used to prepare complementary foods at home and have been reported to be beneficial for enhancing nutritive value (ELMAKI et al., 2007). Thus soaking, which represent a technological process for the removal of soluble compounds, may be an alternative to decrease the content of anti-nutritional compounds present in the pequi peel flour.

The objective of the current study was to analyze the composition of pequi peel flour, and verify the effect of soaking time on the chemical composition, antinutritional factors and in vitro digestibility

1 Department of Biochemistry and Molecular Biology, Federal University of Goias - UFG, Goiânia, GO, Brazil

${ }^{2}$ Department of Food Engineering, School of Agronomy and Food Engineering, Federal University of Goias - UFG, Rod. Goiânia, Km 0, Nova Veneza, CEP 74001-970, Goiânia, GO, Brazil, e-mail: mssoaresjr@hotmail.com

${ }^{*}$ Corresponding author 


\section{Materials and methods}

\subsection{Pequi peel flour preparation}

Pequi fruit from São Miguel do Araguaia, Goiás State, Brazil, were acquired at Goiás State Supply Center (Ceasa-GO) in the city of Goiânia in November $11^{\text {st }}, 2007$. About $15 \mathrm{~kg}$ of fresh fruit were selected according to the size and absence of injury. Fruit were chemically peeled by immersion in a $5.85 \mathrm{~g} \mathrm{~L}^{-1}$ solution for $7 \mathrm{~min}$, followed by washing with water and immersion in a $3 \%(\mathrm{v} / \mathrm{v})$ acetic acid solution for $3 \mathrm{~min}$ (SOARES JÚNIOR et al., 2009). Then the fruit were cut into two parts to separate the external mesocarp (pequi peel) and the internal mesocarp, which was discarded. Pequi peel was sliced, blanched in boiling water for $6 \mathrm{~min}$ and subjected to the soaking process, that occurred by immersion of the slices in water (proportion of 1:3, w/v) at refrigerated temperature $\left(4^{\circ} \mathrm{C}\right)$ for different times $(0,1,2,3$ days - treatments). Then pequi peel were oven-dried at $60{ }^{\circ} \mathrm{C}$ for $16 \mathrm{~h}$, ground to pass through a $0.59 \mathrm{~mm}$ screen, sealed in plastic bags and stored at $4^{\circ} \mathrm{C}$.

\subsection{Chemical composition}

The proximate composition of the flours was determined according to the methods of the Association of Official Analytical Chemists (ASSOCIATION..., 2000). The moisture content was determined by drying the pequi peel flours on a hot air oven at $105{ }^{\circ} \mathrm{C}$ until constant weight. Crude protein content was calculated by converting the nitrogen content determined by macro Kjekdahl's method $(6.25 \times \mathrm{N})$. Crude lipids were extracted from the flours in a Soxhlet extractor with chloroform:methanol $(2: 1, \mathrm{v} / \mathrm{v})$. The contents of crude lipids were determined gravimetrically after oven-drying $\left(80^{\circ} \mathrm{C}\right)$ the extract overnight. Ash content was determined by dry-ashing in a furnace at $525{ }^{\circ} \mathrm{C}$ for $24 \mathrm{~h}$, and total dietary fiber was determined by the enzymatic gravimetric method.

\subsection{Trypsin and $\alpha$-amylase inhibitors}

Samples of pequi peel flour $(1 \mathrm{~g})$ were diluted in a solution of sodium phosphate buffer $(10 \mathrm{~mL}) 0.1 \mathrm{~mL} \mathrm{~L}^{-1} \mathrm{pH} 7.0$, shaken during $1 \mathrm{~h}$ at $4{ }^{\circ} \mathrm{C}$, and then centrifuged (Excelsa II, mod 206$\mathrm{BL}$, São Paulo) at $12000 \mathrm{~g}$ for $15 \mathrm{~min}$ at $4{ }^{\circ} \mathrm{C}$. The precipitate was discarded and the supernatant was denominated crude extract.

The activity of trypsin inhibitors was determined according to Kakade, Rackis and McGhee (1974). Samples of crude extract were incubated with $0.1 \mathrm{~mL}$ trypsin solution $1.0 \mathrm{mg} \mathrm{mL}^{-1}$ and phosphate buffer $0.1 \mathrm{~mol} \mathrm{~L}^{-1} \mathrm{pH} 7.6$ at $37^{\circ} \mathrm{C}$ for $10 \mathrm{~min}$. After that, $0.5 \mathrm{~mL}$ of a casein solution $1 \%(\mathrm{w} / \mathrm{v})$ was added to the solution and the reaction mixture was incubated for $10 \mathrm{~min}$. The reaction was interrupted by adding $1.5 \mathrm{~mL}$ of TCA solution $5 \%$ (v/v). One trypsin unit was arbitrarily defined as the increase of 0.1 absorbance unit at $280 \mathrm{~nm}$. The unit of inhibition (TIU) was defined as the relationship between the units observed in the maximum activity and the activity of the samples containing the inhibitors.

The activity of $\alpha$-amylase inhibitors was determined according to Deshpande et al. (1982). Tests were performed by adding $20 \mu \mathrm{L}$ of crude extract to $60 \mu \mathrm{L}$ of sodium acetate buffer $0.1 \mathrm{~mol} \mathrm{~L}^{-1} \mathrm{pH} 5.0$ and $20 \mu \mathrm{L}$ solution of $\alpha$-amylase from Aspergillus niger. Then, $100 \mu \mathrm{L}$ of $0.5 \%$ starch solution (w/v) in sodium acetate buffer $0.1 \mathrm{~mol} \mathrm{~L}^{-1} \mathrm{pH} 5.0$ were added to each tube. The solution was incubated for $15 \mathrm{~min}$ at $40^{\circ} \mathrm{C}$. After the reaction, $100 \mu \mathrm{L}$ of the mixture were transferred to a test tube containing $900 \mu \mathrm{L}$ of reactive ADNS (acid 3,5-dinitrosalicylic). The system was incubated for $5 \mathrm{~min}$ at $100{ }^{\circ} \mathrm{C}$. After boiling, samples were cooled to $25^{\circ} \mathrm{C}$ and reading of absorbance was done at a wavelength of $550 \mathrm{~nm}$. One unit of $\alpha$-amylase inhibitors was defined as the amount of inhibitors that inhibits one unit of $a$-amylase.

\subsection{Haemagglutinating activity}

Haemagglutination assays, using rabbit erythrocytes, were carried out following the method described by Moreira and Perrone (1977) with modifications. The extracts (1\% w/v) were diluted in 2-fold dilution series against a $0.15 \mathrm{~mol} \mathrm{~L}^{-1} \mathrm{NaCl}$ solution containing $\mathrm{CaCl}_{2}$ and $\mathrm{MnCl}_{2} 5 \mathrm{mmol} \mathrm{L}^{-1} .200 \mu \mathrm{L}$ of a $2 \%(\mathrm{v} / \mathrm{v})$ erythrocyte suspension was added to an equal volume of samples and the mixture incubated at $37^{\circ} \mathrm{C}$ for $30 \mathrm{~min}$ followed by $30 \mathrm{~min}$ at room temperature $\left(25^{\circ} \mathrm{C}\right)$. The tubes were centrifuged (Excelsa II, mod 206-BL, São Paulo) at $12000 \mathrm{~g}$ for $1 \mathrm{~min}$ and the last tube that showed visible agglutination was considered the point of equivalence.

\subsection{Phytic acid determination}

The content of phytic acid present in the flour was determined by the method described by Latta and Eskin (1980) with modifications to the resin DOWEX-4-AGX according to Ellis and Morris (1986). To $1 \mathrm{~g}$ of pequi peel flour it was added $10 \mathrm{~mL}$ of $2.4 \% \mathrm{HCl}$ and stirring was conducted at room temperature $\left(25^{\circ} \mathrm{C}\right)$ for $1 \mathrm{~h}$. The sample was centrifuged at $5000 \mathrm{~g}$ for $10 \mathrm{~min} .2 \mathrm{~mL}$ of supernatant were transferred to a $50 \mathrm{~mL}$ volumetric flask and the volume completed with distilled water. The column was prepared with $0.5 \mathrm{~g}$ of resin DOWEX-AGX-4, eluted with $10 \mathrm{~mL} 0.7 \mathrm{~mol} \mathrm{~L}^{-1} \mathrm{NaCl}$ and $10 \mathrm{~mL}$ of distilled water before elution with the extract. $2 \mathrm{~mL}$ of the extract were applied to the column containing the resin and elution was done with $10 \mathrm{~mL}$ of $0.7 \mathrm{~mol} \mathrm{~L}^{-1} \mathrm{NaCl} .3 \mathrm{~mL}$ of the eluate were added to $1 \mathrm{~mL}$ of Wade reagent and left at room temperature $\left(25^{\circ} \mathrm{C}\right)$ for $15 \mathrm{~min}$. Changes in absorbance were analyzed at $500 \mathrm{~nm}$ and compared with a standard curve of phytic acid (Sigma Aldrich, P8810). Results were expressed in $\mathrm{mg} \mathrm{PA} \mathrm{g}^{-1}$ of the sample.

\subsection{Total phenols and tannins}

The determination of total phenols and tannin in the pequi peel flour was conducted according to the method described by Hagerman and Butler (1978). Samples of pequi peel flour $(0.1 \mathrm{~g})$ were incubated with $10 \mathrm{~mL}$ of distilled water at $85^{\circ} \mathrm{C}$ for $30 \mathrm{~min}$. The solution was cooled to room temperature $\left(25^{\circ} \mathrm{C}\right)$ and centrifuged (Excelsa II, mod 206-BL, São Paulo) at $5000 \mathrm{~g}$ for $5 \mathrm{~min}$. The pellet was discarded and the supernatant used as a source of phenols. 
Total phenols were determined by adding $\mathrm{FeCl}_{3}$ to the extract solutions under alkaline conditions to produce a colored complex with phenols, which was read at $510 \mathrm{~nm}$. Tannin content determined by the Hagerman and Butler (1978) method uses Bovine Serum Albumin (BSA) solution $\left(1 \mathrm{mg} \mathrm{mL}^{-1}\right)$ in $0.2 \mathrm{~mol} \mathrm{~L}^{-1}$ acetate buffer ( $\mathrm{pH}$ 4.9). The extract solutions were precipitated with BSA and, after centrifugation, the precipitate was dissolved in sodium dodecyl sulfate-triethanolamine solution and the tannins were complexed with $\mathrm{FeCl}_{3}$. The colored complex was then read at $510 \mathrm{~nm}$. Total phenol and tannins were measured using tannic acid for standard curves and were expressed as percent tannic acid equivalents.

\subsection{In vitro digestibility tests}

In vitro protein digestibility was determined by a multienzymatic method described by Akeson and Stahmann (1964). Samples of the pequi peel flour were first digested with pepsin (enzyme to substrate ratio $1: 10$ ) at $37^{\circ} \mathrm{C}$ for $3 \mathrm{~h}$. Then, the samples were neutralized with $0.5 \mathrm{M} \mathrm{NaOH}$ solution $(\mathrm{pH}$ 8.0) and, after addition of pancreatin (1:5) the digestion was carried for $4 \mathrm{~h}$ at $37^{\circ} \mathrm{C}$. The digestion was interrupted with trichloroacetic acid and after centrifugation (Excelsa II, mod 206-BL, São Paulo) at $7000 \mathrm{~g}$ for $10 \mathrm{~min}$, the supernatant was assayed according to the method described by Lowry et al. (1951) using bovine serum albumin as standard. The extent of hydrolysis was calculated using $1 \%$ casein solution as control (Equation 1).

$\%$ Digestibility $=\frac{\left(\begin{array}{l}B S A \text { concentration in flour }- \\ B S A \text { concentration in hydrolyzate }\end{array}\right)}{\left(\begin{array}{l}B S A \text { concentration in casein solution }- \\ B S A \text { concentration in hydrolyzate }\end{array}\right)} \times 100$

In vitro starch hydrolysis was determined according to Zabidi and Aziz (2009) with modifications. Two hundred mg of sample were incubated with $1 \mathrm{~mL}$ of a-amylase of Aspergillus niger on water bath at $90{ }^{\circ} \mathrm{C}$ for 15 min under agitation. Then, $200 \mu \mathrm{L}$ of amyloglucosidase solution was added (Sigma-Aldrich) and incubated at $55^{\circ} \mathrm{C}$ for $120 \mathrm{~min}$ under continuous agitation. The reducing sugar was determined as described by Miller (1959). Flour starch digestion was expressed as a percentage of the reducing sugar obtained after hydrolysis, using 1\% (w/v) starch solution as control (Equation 2).

$\%$ Digestibility $=\frac{\left(\begin{array}{l}{[\text { reducing suggar }] \text { in hydrolyzate }-} \\ {[\text { reducing suggar }] \text { in flour }}\end{array}\right)}{\left(\begin{array}{l}{[\text { reducing suggar }] \text { in hydrolyzate }-} \\ {[\text { reducing suggar }] \text { in starch solution }}\end{array}\right)} \times 100$

\subsection{Statistical analysis}

A completely random experimental design was used with four treatments and five repetitions, evaluating the content of moisture, ash, protein, lipids, total, soluble and insoluble dietary fiber, phytic acid, haemagglutinating activity. All analysis was run on triplicate. Statistica 6.0 (StatSoft Inc., Tulsa, USA) was used to run ANOVA followed by Tukey's test to determine the significance among the means. The level of significance used was $5 \%$. The total phenols, tannins, protein and starch digestibility were determined only at zero and $24 \mathrm{~h}$ of soaking time. Descriptive statistics was used for this data evaluation.

\section{Results and discussion}

\subsection{Chemical composition}

The mean moisture contents of the pequi peel flours were low $\left[0.48-1.54 \mathrm{~g}(100 \mathrm{~g})^{-1}\right]$ and decreased over maceration time (Table 1$)$. The flours differed $(\mathrm{P}<0.05)$ with respect to moisture content, except the flour obtained with a maceration time of 48 $h$, which was not significantly different $(\mathrm{P}>0.05)$ from those obtained with 24 and $72 \mathrm{~h}$ of maceration. Pequi peel flours can be considered products with good physical and chemical stability, as long as stored adequately in hermetically sealed packages.

The data obtained allow affirming that the pequi peel flour is a good source of nutrients, especially soluble and insoluble fiber contents. There was no significant difference $(\mathrm{P}>0.05)$ in the protein contents of the pequi peel flours subjected to different times of maceration, but these were different from the non-macerated flour $(\mathrm{P}<0.05)$. The protein contents of the macerated pequi peel flours were close to the values found by Vera et al. (2007) for pequi pulp, which varied from $3.18 \%$ to $3.89 \%$. On the other hand, the non-macerated flour presented a protein content close to that found by Roesler et al. (2007) in the flour from the peel of Anonna crassiflora Mart. [2.14 $\mathrm{g}(100 \mathrm{~g})^{-1}$ ] and in the flour from the peel of Solanum lycocarpum St. Hil.lobeira $\left[2.51 \mathrm{~g}(100 \mathrm{~g})^{-1}\right]$.These are fruits from the Brazilian savanna with potential for commercialization as flour, mainly due to their abundance and functional characteristics.

The total lipids varied between $\left[1.3-4.0 \mathrm{~g}(100 \mathrm{~g})^{-1}\right]$. The lowest value for lipids was found in the non-macerated flour $(\mathrm{P}<0.05)$. However there was an increase in the lipid content with maceration as also for the protein and fiber contents (Table 1). Soares Júnior et al. (2010), studying the pequi peel flour, found lower total lipid content $\left[0.85 \mathrm{~g}(100 \mathrm{~g})^{-1}\right]$ than that found in the non-macerated flour in the present study, probably due to the non-removal of the epicarp (lipid-rich) in the elaboration of the flour. The lipid content for the flours obtained with different maceration times were higher than verified by Soares Júnior et al. (2009) in pequi peel flour [0.88 g (100 g $)^{-1}$, principally in those underwent maceration. The increase in the lipid content, as also in the protein and dietary fiber content, after maceration of the pequi peel, was probably related to the decrease in the content of carbohydrates and water soluble salts by leaching into the maceration water, resulting in a proportional increase in the contents of both components.

Unlike proteins and lipids, the ash content decreased with maceration due to the high water solubility of the minerals. The highest ash content was found in the non-macerated pequi peel flour, significantly different from the others $(\mathrm{P}<0.05)$. There was no significant difference in the mineral content between macerated flours $(\mathrm{P}>0.05)$. Soares Júnior et al. (2010), in a study with pequi peel flour, registered $\left[2.86 \mathrm{~g}(100 \mathrm{~g})^{-1}\right]$ of ash, a value higher than found in the non-macerated flour in the present study. This was probably due to the removal of the epicarp by 
leaching, which is a tissue rich in ash as well as lipids. However these values were lower than in the macerated pequi peel flours, due to leaching during maceration.

The total, soluble and insoluble dietary fiber contents of the non-macerated pequi peel flours were high, 59.67, 24.27 and $35.4 \mathrm{~g}(100 \mathrm{~g})^{-1}$, respectively. However, after maceration of the peel during processing, the values were even higher, reaching $91 \mathrm{~g}(100 \mathrm{~g})^{-1}$ total dietary fiber, $36.5 \mathrm{~g}(100 \mathrm{~g})^{-1}$ soluble dietary fiber and $54.4(100 \mathrm{~g})^{-1}$ insoluble dietary fiber $(\mathrm{dwb})$. Thus there was an increase in the total, soluble and insoluble dietary fiber contents with increased maceration time up to $48 \mathrm{~h}$. The pequi peel flours differed $(\mathrm{P}<0.05)$ with respect to the total, soluble and insoluble dietary fiber contents, with the exception of those obtained with $48 \mathrm{~h}$ and $72 \mathrm{~h}$ of maceration $(\mathrm{P}>0.05)$.

There are currently many studies being carried out with fruit peels with the objective of verifying the nutritional and functional value of these residues, which for decades were usually discarded by the consumers. Fruit peels such as those of the passion flower (Passiflora edulis flavicarpa DEG.) show a total dietary fiber content of $57.32 \mathrm{~g}(100 \mathrm{~g})^{-1}$ (CORDOVA et al., 2005); and the bran composed of pera orange peel and bagasse contains $11.04 \mathrm{~g}(100 \mathrm{~g})^{-1}$ dietary fiber (RUVIARO et al., 2008). The insoluble fiber content in the fibrous residues from a cassava starch factory reached maximum values of $25.1 \mathrm{~g}(100 \mathrm{~g})^{-1}$ (RAUPP et al., 1999). All the above mentioned residues showed much lower total, soluble and insoluble dietary fiber contents than the pequi peel flour [59.67 $\left.\mathrm{g}(100 \mathrm{~g})^{-1}\right]$.

Dietary fiber is composed of an insoluble part and a soluble part. The insoluble fraction is related to increasing the fecal ball, thus guaranteeing intestinal peristalsis, avoiding constipation and annulling the appearance of hemorrhoids and diverticulitis. The soluble fraction, on the other hand, has proven beneficial effects on the metabolism of insulin and cholesterol. Thus the ingestion of pequi peel flour, whether pure or in the form of bread, cake or pasta, could contribute considerably to the good functioning of the intestine and prevent increases in blood cholesterol levels. It can also be consumed by diabetics, since the water soluble fibers exert a hyperglycemic effect by delaying gastric emptying, shortening the intestinal transit and reducing glucose absorption (CORRÊA, 2002).

\subsection{Antinutritional factors}

The presence of antinutritional factors in plant products must be analyzed to ensure that the nutritional quality is not compromised by any of these components. As observed in Table 2, haemagglutination activity and $\alpha$-amylase inhibitors were not detected in the pequi peel flour.

In the assay for lectins, there was no hemagglutination of erythrocytes in any of the tubes, characterizing the absence of hemagglutinins in the extracts. To the contrary, the erythrocytes were completely hydrolyzed. In this way, the assay was repeated using an extract previously heated at $100{ }^{\circ} \mathrm{C}$ for $5 \mathrm{~min}$, thus determining the presence of hemolysins, due to the non-hydrolysis of the erythrocytes. Accordingly, thermal treatments above $100{ }^{\circ} \mathrm{C}$ such as cooking and roasting, are sufficient to eliminate this anti-nutritional component, present in the pequi skin flours. On the other hand, hemolysins are important compounds from the biotechnological point of view, given the potential bactericidal and anticancer activities (YULDASHEVA et al., 2005).

From the nutritional point of view, the absence of an a-amylase inhibitor in the pequi peel flour was interesting because these antinutritional factors are responsible for reducing the rate of starch digestion in the mouth and small intestine, affecting the release of glucose into the blood (FUNKE;

Table 1. Moisture, protein, lipid, ash, total dietary, soluble and insoluble fiber value (dwb) of pequi peel flours as a function of soaking time (h).

\begin{tabular}{lcccc}
\hline \multicolumn{1}{r}{$\begin{array}{c}\text { Component } \\
{\left[\mathrm{g}(100 \mathrm{~g})^{-1}\right]}\end{array}$} & \multicolumn{4}{c}{ Soaking time $(\mathrm{h})$} \\
\cline { 2 - 5 } \multicolumn{1}{c}{} & 0 & 24 & $0.58^{\mathrm{bc}} \pm 0.02$ & 78 \\
\hline Moisture & $1.54^{\mathrm{a}} \pm 0.03$ & $3.42^{\mathrm{a}} \pm 0.16$ & $3.39^{\mathrm{a}} \pm 0.09$ & $0.48^{\mathrm{c}} \pm 0.10$ \\
Protein & $2.65^{\mathrm{b}} \pm 0.08$ & $3.97^{\mathrm{a}} \pm 0.05$ & $3.76^{\mathrm{b}} \pm 0.07$ & $3.48^{\mathrm{a}} \pm 0.04$ \\
Lipid & $1.32^{\mathrm{c}} \pm 0.02$ & $1.21^{\mathrm{b}} \pm 0.01$ & $1.16^{\mathrm{b}} \pm 0.07$ & $3.93^{\mathrm{a}} \pm 0.03$ \\
Ash & $2.09^{\mathrm{a}} \pm 0.02$ & $91.0^{\mathrm{a}} \pm 0.75$ & $1.11^{\mathrm{b}} \pm 0.04$ \\
Total dietary fiber & $59.67^{\mathrm{c}} \pm 0.97$ & $78.17^{\mathrm{b}} \pm 0.87$ & $36.5^{\mathrm{a}} \pm 0.6$ & $91.47^{\mathrm{a}} \pm 0.82$ \\
Soluble dietary fiber & $24.27^{\mathrm{c}} \pm 1.01$ & $31.47^{\mathrm{b}} \pm 1.01$ & $37.0^{\mathrm{a}} \pm 0.61$ \\
Insoluble dietary fiber & $35.4^{\mathrm{c}} \pm 0.1$ & $46.7^{\mathrm{b}} \pm 0.17$ & $54.4^{\mathrm{a}} \pm 0.17$ & $54.47^{\mathrm{a}} \pm 0.21$ \\
\hline
\end{tabular}

Means followed by the same letter in the same row are not significantly different $(\mathrm{P}<0.01)$ according to Tukey's test.

Table 2. Hemagglutinating activity, $\alpha$-Amylase and Trypsin inhibitor (UI), and Phytic acid content of pequi peel flours as a function of soaking time (h).

\begin{tabular}{lcccc}
\hline \multicolumn{1}{r}{$\begin{array}{c}\text { Component } \\
{\left[\mathrm{g}(100 \mathrm{~g})^{-1}\right]}\end{array}$} & 0 & 24 & Soaking time $(\mathrm{h})$ & \\
\cline { 2 - 5 } & - & - & - & - \\
\hline Haemagglutination & - & - & - & - \\
$\alpha$-Amylase inhibitor & $1.50 \pm 0.56$ & - & - & - \\
Trypsin inhibitor & $0.40^{\mathrm{a}} \pm 0.03$ & $0.33^{\mathrm{a}} \pm 0.05$ & $0.11^{\mathrm{b}} \pm 0.002$ & $0.00^{\mathrm{b}}$ \\
Phytic acid $^{1}$ & &
\end{tabular}

${ }^{1}$ Means followed by the same letter in the same row are not significantly different $(\mathrm{P}<0.01)$ according to Tukey's test 
MELZING, 2006). This is common in cereals such as wheat, barley, corn, rye and rice; in leguminous seeds such as beans and also in fruit such as mango. After forming the inhibitor-substrate complex, this is quite thermally stable and can even resist cooking (MIZUBUTI; IDA, 1999). The presence of $\alpha$-amylase is necessary from a technological point of view, since when mixed with other flours for the elaboration of bread, cakes and pasta in general, it can act on the $\alpha 1,4$ bonds of the starch producing oligosaccharides, which serve as a fermentable substrate for yeast, conferring shorter times on the fermentation period (DAMODARON; PARKIN; FENNEMA, 2010).

On the other hand, the trypsin inhibitor content decreased considerably after soaking. The reduction of trypsin inhibitors by this process may be due to the water-soluble nature of the inhibitors that permits migration from the flour into the soaking medium (EL-HADY; HABIBA, 2003) or to the extraction of ions essential for the inhibitors activity (PIERGIOVANNI; GATTA, 1994). This result calls attention to the possibility of consuming non-macerated pequi peel flour, since this kind of inhibitor can cause indigestibility if consumed in large amounts, thus prejudicing the gastrointestinal tract of the organism (SGARBIERI, 1996). The ingestion of large amounts of trypsin inhibitor leads to a super-production of pancreatic proteolytic enzymes, which can represent an important loss in sulfur amino acids (LIENER, 1994). Trypsin inhibitors are usually inactivated by thermal treatment (VEN; MATSER; BERG, 2005). However, this procedure is costly and may result in the loss of essential amino acids, thus, soaking should be an option to reduce costs and preserve nutritional quality.

There was a significant reduction in the phytic acid content with increased maceration time. After three days, the presence of phytic acid was no longer detected (Table 2), indicating that the process was efficient to eliminate this type of antinutritional substance. According to Hossain and Becker (2002), the decrease in the phytic acid content during the soaking of Sesbania spp. seed flour was caused by leaching of the phytate ions into the water due to the influence of a concentration gradient, and the loss is a function of the cell permeability acquired by the grain. Oliveira et al. (2001) observed a reduction in the phytate content $(85 \%)$ in beans using soaking. The phytate content of oat flour was found to be $0.74 \mathrm{~g}(100 \mathrm{~g})^{-1}$ and that of rice flour $0.55 \mathrm{~g}(100 \mathrm{~g})^{-1}$ (GARCÍA-ESTEPA; GUERRA-HERNÁNDEZ; GARCÍA-VILLANOVA, 1999), values higher than found in the non-soaked pequi peel flours. On evaluating the bioavailability of iron in meals consisting of rice, beans, meat and tomato, Fantini et al. (2008) reported that the values of $0.09 \mathrm{~g}(100 \mathrm{~g})^{-1}$ and $0.2 \mathrm{~g}(100 \mathrm{~g})^{-1}$ for Phytic acid played no inhibitory effect.

The structure of the phytic acid suggests a tremendous chelating potential, so it is believed to interfere with mineral bioavailability in humans (GRAF; EATON, 1990). On the other hand, phytic acid has been reported to possess various significant health benefits including its potential as antioxidant and anticancer agent (JARIWALLA, 2001). Anticancer activity of phytic acid has been demonstrated both in vivo and in vitro, which is based on the hypothesis that exogenously administered phytic acid may be internalized, dephosphorylated to IP(1-5) and thus can inhibit cell growth. Furthermore, due to its relatively high binding affinity for iron, phytic acid arouses great interest as a potential food preservative (STODOLAK et al., 2007).

Pequi peel flour presented high levels of total phenols and tannins, whose content decreased slightly with soaking by $24 \mathrm{~h}$ (Table 3). Reduction of phenols and tannins was around 8.5\% and $19.0 \%$, respectively, probably due to the low solubility of these compounds in water (WATERMAN; MOLE, 1994). This low reduction may be also related to the binding of polyphenols with other organic substances, such as proteins or carbohydrates, forming insoluble aggregates (SAXENA; CHADHA; SHARMA, 2003).

Tannins also present toxic activity, probably due to their ability to bond to the proteins and other macromolecules. They are considered to be nutritionally undesirable since they precipitate proteins, inhibit digestive enzymes and affect the use of the vitamins and minerals (MONTEIRO et al., 2005). However, they are capable of reacting with free radicals, which can be formed naturally by the metabolism, during physical exercise or even by exposure to sunlight. They also show the capacity to scavenge radicals such as the hydroxyl, superoxide and peroxyl radicals, compounds of importance in the prooxidant cell state (PIMENTEL; FRANCKI; GOLLUCKE, 2005).

\subsection{In vitro protein and starch digestibility}

The value of in vitro protein digestibility of soaked flour for $24 \mathrm{~h}$ was $6.2 \%$ lower than the non-soaked one (Table 3). The small reduction in protein digestibility on PPFS may be related to the polyphenol content of samples, since high-molecularweight structures, usually designated as tannins, have the ability to interact with proteins. Hydrogen bonding is thought to be augmented by hydrophobic phenomena in which the aromatic nuclei of the tannin interact with hydrophobic regions in proteins, rendering them unavailable for absorption by the human body (HASLAM, 1989). The results agree with those of Oliveira et al. (2001) who observed reduction in protein digestibility of soaked common bean compared to non-soaked ones.

Pequi peel flour presented reduced starch digestibility, but the soaking process was effective for improving $24 \%$ of its value (Table 3). Starch digestibility depends on the amount of susceptible starch to the $\alpha$-amylase and amyloglucosidase activity and on the structural characteristics of the starch grain. The amylose/amylopectin rate and the molecular structure of amylopectin can also interfere with starch digestibility

Table 3. In vitro protein and starch digestibility (\%), total phenols and tannins ( $\mathrm{mg} \mathrm{g}^{-1}$ of flour) in pequi peel flours as a function of soaking time (h).

\begin{tabular}{lcc}
\hline \multirow{2}{*}{ Component } & \multicolumn{2}{c}{ Soaking time (h) } \\
\cline { 2 - 3 } & 0 & 24 \\
\hline Protein digestibility & $79.80 \pm 0.25$ & $74.82 \pm 0.25$ \\
Starch digestibility & $36.19 \pm 1.28$ & $44.94 \pm 1.07$ \\
Total Phenols & $85.60 \pm 0.78$ & $78.34 \pm 0.23$ \\
Tannins & $14.51 \pm 0.12$ & $11.75 \pm 0.31$ \\
\hline
\end{tabular}


(SANDHU; LIM, 2008). High amylose content leads to greater amount of resistant starch, which negatively influences the digestibility (THARANATHAN; MAHADEVAMMA, 2003).

\section{Conclusions}

Soaking constitutes a viable process with several technological applications. In this study, soaking was important to reduce antinutritional factors, such as trypsin inhibitors and phytic acid, and improve starch digestibility, thus conferring improvement of nutritional characteristics to the pequi peel flour. Soaking, which consists of a simple and inexpensive treatment, was efficient to improve the nutritional characteristics of the pequi peel flour, opening up possibilities for its use in food formulations.

\section{Acknowledgments}

To CNPq for the scholarship.

\section{References}

AKESON, W. R.; STAHMANN, M. A. A pepsin pancreatin digest index of protein quality evaluation. Journal of Nutrition, v. 83, n. 64, p. 257-261, 1964. PMid:14191426.

ASSOCIATION OF OFFICIAL ANALYTICAL CHEMISTS - AOAC. Official methods of analysis. Washington: AOAC, 2000.

CORDOVA, K. V. et al. Características físico-químicas da casca do maracujá amarelo (Passiflora edulis Flavicarpa Degener) obtida por secagem. Boletim CEPPA, v. 23, p. 221-230, 2005.

CORREAA, A. D. Fibras na prevenção de doenças. Lavras: FAEPE, 2002. 43 p.

DAMODARON, S.; PARKIN, K. L.; FENNEMA, O. R. Química de alimentos de Fennema. São Paulo: Artmed, 2010. 900 p.

DESHPANDE, S. S. et al. Effects of dehulling on phytic acid, polyphenols, and enzyme inhibitorss of dry beans (Phaseolus vulgaris L.). Journal of Food Science, v. 47, n. 6, p. 1846-1850, 1982. http://dx.doi.org/10.1111/j.1365-2621.1982.tb12896.x

EL-HADY, E. A. A.; HABIBA, R. A. Effect of soaking and extrusion conditions on antinutrients and protein digestibility of legume seeds. LWT - Food Science \& Technology, v. 36, n. 3, p. 285-293, 2003.

ELMAKI, H. B. et al. Content of antinutritional factors and $\mathrm{HCl}$-extractability of minerals from white bean (Phaseolus vulgaris) varieties: Influence of soaking and/or cooking. Food Chemistry, v. 100, p. 362-368, 2007. http://dx.doi.org/10.1016/j. foodchem.2005.09.060

FANTINI, A. P. et al. Disponibilidade de ferro em misturas de alimentos com adição de alimentos com alto teor de vitamina C e de cisteína. Ciência e Tecnologia de Alimentos, v. 28, p. 435-439, 2008. http:// dx.doi.org/10.1590/S0101-20612008000200026

FUNKE, I.; MELZIG, M. F. Traditionally used plants in diabetes theraphy-phytotherapeutics as inhibitorss of alfa-amylase activity. Revista Brasileira de Farmacognosia, v. 16, n. 1, p. 1-5, 2006. http:// dx.doi.org/10.1590/S0102-695X2006000100002

GARCÍA-ESTEPA, R. M.; GUERRA-HERNÁNDEZ, E.; GARCÍAVILLANOVA, B. Phytic acid content in milled cereal products and breads. Food Research International, v. 32, p. 217-221, 1999. http://dx.doi.org/10.1016/S0963-9969(99)00092-7
GRAF, E.; EATON, J. W. Antioxidant functions of phytic acid. Free Radical Biology \& Medicine, v. 8, n. 1, p. 61-69, 1990. http://dx.doi. org/10.1016/0891-5849(90)90146-A

HAGERMAN, A. E.; BUTLER, L. G. Protein precipitation method for the quantitative determination of tannins. Journal of Agricultural and Food Chemistry, v. 26, n. 4, p. 809-812, 1978. http://dx.doi. org/10.1021/jf60218a027

HASLAM, E. Plant polyphenols-vegetable tannins revisited. Cambridge: Cambridge University Press, 1989. 230 p.

HOSSAIN, M. A.; BECKER, K. In vitro rumen degradability of crude protein in seeds from four Sesbania spp. and the effects of treatments designed to reduce the levels of antinutrients in the seeds. Animal Feed Science and Technology, v. 95, p. 49-62, 2002. http://dx.doi. org/10.1016/S0377-8401(01)00310-8

JARIWALLA, R. J. Rice-bran products: phytonutrients with potential applications in preventive and clinical medicine. Drugs under Experimental and Clinical Research, v. 27, n. 1, p. 17-26, 2001. PMid:11276826.

KAKADE, M. L.; RACKIS, J. J.; McGHEE, J. E. Determination of trypsin inhibitor activity of soy products: a collaborative analysis of an improved procedure. Cereal Chemistry, v. 51, p. 376-382, 1974.

LATTA, M.; ESKIN, M. A simple and rapid colorimetric method for phytate determination. Journal of Agricultural and Food Chemistry, v. 28, p. 1313-1315, 1980. http://dx.doi.org/10.1021/ jf60232a049

LIENER, I. E. Implications of antinutritional components in soybean foods. Critical Reviews in Food Science and Nutrition, v. 34, p. 31-67, 1994. PMid:8142044. http://dx.doi. org/10.1080/10408399409527649

LORENZI, H. Árvores brasileiras. 5. ed. Nova Odessa: Plantarum, 2008. $176 \mathrm{p}$

MELO JÚNIOR, A. F. et al. Estrutura genética de populações naturais de pequizeiro (Caryocar brasiliense Camb.). Scientia Forestalis, v. 66, p. 56-65, 2004.

LOWRY, O. H. et al. Protein measurement with folin phenol reagent. Journal Biology and Chemistry, v. 193, p. 263-275, 1951.

MILLER, G. L. Use of dinitrosalicylic acid reagent for determination of reducing sugar. Analytical Chemistry, v. 31, p. 426-428, 1959. http://dx.doi.org/10.1021/ac60147a030

MIZUBUTI, I. Y.; IDA, E. I. Constituintes antinutricionais e seus efeitos indesejáveis na alimentação. Semina, v. 20, p. 107-112, 1999.

MONTEIRO, J. M. et al. Taninos: uma abordagem da química à ecologia. Química Nova, v. 28, p. 892-896, 2005. http://dx.doi. org/10.1590/S0100-40422005000500029

MOREIRA, R. A.; PERRONE, J. C. Purification and partial characterization of a lectin from Phaseolus vulgaris. Plant Physiology, v. 59, p. 783-787, 1977. http://dx.doi.org/10.1104/ pp.59.5.783

OLIVEIRA, A. C. et al. O processamento doméstico do feijão-comum ocasionou uma redução nos fatores antinutricionais fitatos e taninos, no teor de amido e em fatores de flatulência rafinose, estaquiose e verbascose. Archivos Latinoamericanos de Nutrición, v. 51, p. 276-283, 2001. PMid:11795242.

PIERGIOVANNI, A. R.; GATTA, C. D. $a$-Amylase inhibitorss in cowpea: Effects of soaking and cooking methods. Food Chemistry, v. 51, p. 79-81, 1994. http://dx.doi.org/10.1016/03088146(94)90051-5

PIMENTEL, C. V. M. B.; FRANCKI, V. M.; GOLLUCKE, A. P. B. Alimentos funcionais: introdução às principais substancias bioativas em alimentos. São Paulo: Varela, 2005. 95 p. 
RAUPP, D. S. et al. Composição e propriedades fisiológico-nutritivas de uma farinha rica em fibra insolúvel obtida do resíduo fibroso de fecularia de mandioca. Ciência e Tecnologia de Alimentos, v. 19, p. 205-210, 1999. http://dx.doi.org/10.1590/S010120611999000200009

ROESLER, R. et al. Atividade antioxidante de frutas do cerrado. Ciência e Tecnologia de Alimentos, v. 27, p. 53-60, 2007. http://dx.doi. org/10.1590/S0101-20612007000100010

RUVIARO, L. et al. Análise sensorial de sobremesa acrescida a farelo de casca e bagaço de laranja entre universitarios de Guarapuava (PR). Revista Salus-Guarapuava, v. 2, p. 41-50, 2008.

SANDHU, K. S.; LIM, S. T. Digestibility of legume starches as influenced by their physical and structural properties. Carbohydrate Polymers, v. 71, n. 2, p. 245-252, 2008. http://dx.doi.org/10.1016/j. carbpol.2007.05.036

SAXENA, A. K.; CHADHA, M.; SHARMA, S. Nutrients and antinutrients in chickpea (Cicer arietinum $\mathrm{L}$.) cultivars after soaking and pressure cooking. Journal of Food Science and Technology, v. 40, n. 5, p. 493-497, 2003.

SGARBIERI, V. C. Proteínas em alimentos protéicos: propriedades, degradações, modificações. São Paulo: Varela, 1996. 517 p.

SIQUEIRA, B. S. et al. Pectina extraída de casca de pequi e aplicação em geleia light de manga. Revista Brasileira de Fruticultura, v. 34 , p. 560-567, 2012. http://dx.doi.org/10.1590/S010029452012000200030

SOARES JÚNIOR, M. S. et al. N. Development and chemical characterization of flour obtained from external mesocarp of "pequizeiro" fruit. Ciência e Tecnologia de Alimentos, v. 30, p. 940 948, 2010. http://dx.doi.org/10.1590/S0101-20612010000400017

SOARES JÚNIOR, M. S. et al. Qualidade de biscoitos formulados com diferentes teores de farinha de casca de pequi. Pesquisa Agropecuária Tropical, v. 39, p. 98-104, 2009.
STODOLAK, B. et al. The effect of phytic acid on oxidative stability of raw and cooked meat. Food Chemistry, v. 101, n. 3, p. 1041-1045, 2007. http://dx.doi.org/10.1016/j.foodchem.2006.02.061

THARANATHAN, R. N.; MAHADEVAMMA, S. Grain legumes: a boon to human nutrition. Trends in Food Science and Technology, v. 14, n. 12 , p. $507-518,2003$. http://dx.doi.org/10.1016/j. tifs.2003.07.002

UNIVERSIDADE ESTADUAL DE CAMPINAS - UNICAMP. Tabela brasileira de composição de alimentos - TACO. Campinas: UNICAMP/NEPA, 2004.

WATERMAN, P. G.; MOLE, S. Analysis of phenolic plant metabolites. Oxford: Blackwell Scientific Publications, 1994. 238p.

VEN, C.; MATSER, A. M.; BERG, R. W. Inactivation of Soybean Trypsin Inhibitorss and Lipoxygenase by High-Pressure Processing. Journal of Agricultural and Food Chemistry, v. 53, p. 1087-1092, 2005. PMid:15713024. http://dx.doi.org/10.1021/jf048577d

VERA, R. et al. A. Caracterização física e química de frutos do pequizeiro (Caryocar brasiliense Camb.) oriundos de duas regiões no Estado de Goiás, Brasil. Pesquisa Agropecuária Tropical, v. 37, p. 93-99, 2007.

YULDASHEVA, L. N. et al. Cholesterol-dependent hemolytic activity of Passiflora quadrangularis leaves. Brazilian Journal of Medical and Biological Research, v. 38, p. 1061-1070, 2005. PMid:16007277. http://dx.doi.org/10.1590/S0100-879X2005000700009

ZABIDI, M. A.; AZIZ, N. A. A. In vitro starch hydrolysis and estimated glycaemic indez of bread substituted with different percentege of chempedak (Artocarpus integer) seed flour. Food Chemistry, v. 117, n. 1, p. 64-68, 2009. http://dx.doi.org/10.1016/j. foodchem.2009.03.077 